\title{
ANALYSIS OF SPEED AND SOCIAL-PSYCHOLOGY FACTORS OF SPEEDING BEHAVIOUR ON DRIVERS IN DKI JAKARTA
}

\section{Analisis Kecepatan Mengemudi dan Faktor Sosial Psikologis Perilaku Mengebut pada Pengemudi di DKI Jakarta}

\author{
Andyka Kusuma \\ Department of Civil Engineering \\ University of Indonesia \\ Kampus Baru UI Depok \\ Depok, West Java \\ andyka.k@eng.ui.ac.id
}

\author{
Dewi Maulina \\ Faculty of Psychology \\ University of Indonesia \\ Kampus Baru UI Depok \\ Depok, West Java \\ dewi.maulina140105@gmail.com
}

\author{
Almatrisa Mustikha Hutami \\ Department of Civil Engineering \\ University of Indonesia \\ Kampus Baru UI Depok \\ Depok, West Java \\ almatrisamustikha@gmail.com
}

\begin{abstract}
Increased vehicle speed will affect the increase in reaction time and distance to stop and the increased possibility of errors that can be done by the driver. The most common cause of accidents faced by many countries is a high speed and exceeding permitted limits because they contribute to the problem of the number and number of fatalities of accident victims. Setting the maximum speed limit can reduce the risk of accidents. The higher the speed, the greater the stop distance needed, and the risk of accidents increases.
\end{abstract}

Keywords: speed, safety, maximum speed limit

\begin{abstract}
Abstrak
Kecepatan kendaraan yang meningkat akan berpengaruh terhadap peningkatan waktu reaksi dan jarak untuk berhenti serta meningkatnya kemungkinan kesalahan yang dapat dilakukan oleh pengemudi. Faktor penyebab kecelakaan yang paling sering dihadapi oleh banyak negara adalah kecepatan tinggi dan melebihi batas yang diijinkan karena ikut berkontribusi pada permasalahan jumlah dan kefatalan korban kecelakaan. Mengatur batas kecepatan maksimum dapat menurunkan resiko kecelakaan. Semakin tinggi kecepatan, maka semakin besar jarak berhenti yang dibutuhkan dan resiko kecelakaan semakin meningkat.
\end{abstract}

Kata kunci: kecepatan, keselamatan, batas kecepatan maksimum

\section{INTRODUCTION}

Speed has been identified as one of the main risk factors for accidents in Indonesia. In the aspect of traffic and vehicle aspects of regulation, control, and traffic control need to be considered, one example of which is by recommending the design speed or plan speed on a road segment. Traffic stakeholders encourage speed limits on the road, starting from the design process to the operational speed of the road. In high-income countries, speed contributes to around $30 \%$ of road deaths, while in some low- and middle-income countries, speed is expected to be a major contributing factor to accidents.

The phenomenon of speed limit violations is a driver's behaviour that exceeds the speed limit that has been determined through applicable regulations adjusted to the road characteristics and traffic conditions on the road. Driving behaviour above regulated speed limits certainly has potential causes of accidents resulting in mortality and morbidity. Therefore, controlling the speed of the vehicle is one way to reduce the potential for accidents and the risk of severity of the victim. 
In metropolitan areas such as Jakarta and surrounding areas, there was an increase in accident rates compared to the previous year. Based on data compiled by the Law Enforcement Sub directorate (Gakkum Subdit) of the Metro Jaya Regional Police Headquarters, there were 5,400 accidents from January to November 2018. The number of these accidents increased by five per cent compared to 2017. Among the various vehicle users, traffic accidents were found mostly in motorcycle rider. In 2018, there was an increase in the number of motorcycle traffic accidents totalling 4,255 accidents (Wahid, 2018 in https://news.detik.com/berita/d-4352016/angka-kec accident-di-Jakarta increasingbike- motorbike-dominating).

Looking at the description of driving behaviour in urban areas, this study tries to understand better traffic factors that encourage drivers to drive above the speed limit set for urban roads, both drivers of two-wheeled vehicles and four-wheeled vehicles. Furthermore, this study explores social psychological factors that play a role in the behaviour of "speeding" displayed by two-wheeled and four-wheeled drivers. Therefore, this study focuses on urban arterial segments 6/2D by combining past data, speed, and questionnaires to obtain the intended factors. Speed analysis is needed to determine the variation between plan speed and operation.

\section{LITERATURE REVIEW}

\section{Roads}

Roads are land transportation infrastructures which cover all parts of the road, including complementary buildings and equipment intended for traffic, which are at ground level, above ground level, under the surface and or water, and above the surface of the water, except roads railroad, lorry and cable roads (Republic of Indonesia Government Regulation No. 34 of 2006).

\section{Speeds}

Driving at high speed is one of the serious public and social health problems in all countries. This is also a complex problem involving techniques, driving behaviour, education, and law enforcement.

Speed has many positive effects, especially allowing reduced travel time and increasing mobility. Progress in terms of roads over the past century has significantly reduced travel time and contributed to national economic development, facilitated access to jobs, goods and services, and facilities such as hospitals, entertainment, and shopping centres, and in turn, expanded opportunities for housing, employment, etc. This progress has contributed to improving the quality of life in general. Speed also has some strong negative consequences (ex. On road safety and the environment) and contributes to a significant negative impact on living levels in residential and urban areas.

Often, the driver exceeds the speed limit of less than $20 \mathrm{~km} /$ hour. But the proportion of drivers travelling at speeds of more than $20 \mathrm{~km} / \mathrm{h}$ above the limit. Speed up regarding all types of motorized vehicles and all groups of road users. However, young drivers are the group most involved in speeding behaviour. The significant adverse impact of road safety on higher vehicle speeds has been confirmed by extensive research. Many researchers have modelled the relationship between serious accidents, fatal accidents, and speed. The 
famous Nilsson 1 "Power Model" leads to the broad relationships illustrated in the chart and the following estimates about the impact of changes in average speed on fatal accidents, fatal and serious injury accidents and all injury accidents (Transport Research Center, 2006) :

1. $5 \%$ increase in average speed causes around a $10 \%$ increase in all injury accidents and a $20 \%$ increase in fatal accidents. The same research shows the positive impact of reducing vehicle speed:

2. 5\% reduction in average speed caused around a 10\% decrease in accident accidents and a $20 \%$ reduction in fatal accidents. A very important and relatively new development in overcoming the problem of speeding is recognizing and acting on the threshold of the physical resistance of the human body to the energy released during a collision (which is related to the impact speed).

This threshold needs to be an important input for the development of laws, regulations, and infrastructure. For example, according to the World Health Organization, pedestrians run the risk of $80 \%$ being killed at a collision speed of $50 \mathrm{~km} /$ hour, while this risk decreases to $10 \%$ at $30 \mathrm{~km} / \mathrm{hr}$. For passenger cars, wearing a seat belt in a well-designed car can protect a maximum of $70 \mathrm{~km} / \mathrm{h}$ in a frontal impact and $50 \mathrm{~km} / \mathrm{h}$ in a side impact.

\section{Speed Plan}

Government Regulation number 79 of 2013. Furthermore, article 23, paragraph four (4), Part Two, concerning Speed Limits, is stated, the speed limit as referred to as stipulated as follows. The speed limit as referred to in paragraph (2) and paragraph (3) is:

1. at least 60 (sixty) kilometres per hour in free-flow conditions and a maximum of 100 (one hundred) kilometres per hour for highways;

2. maximum of 80 (eighty) kilometres per hour for intercity roads;

3. maximum of 50 (fifty) kilometres per hour for urban areas; and

4. maximum of 30 (thirty) kilometres per hour for residential areas.

\section{Speed of 85 percentiles}

85 percentile speed is the speed of traffic where $85 \%$ of vehicle users drive their vehicles on the road without being affected by lower traffic speeds or bad weather (Abraham, 2001). So that the speed of 85 percentiles can be said as the speed used by 85 percentiles of the driver, which is expected to represent the speed that is often used by the driver on the road (Sendow, 2004).

\section{What Factors Affect Speed}

Drivers' speed choice is influenced by several factors that can be considered as:

1. driver-related factors (age, gender, alcohol level, number of people in the vehicle);

2. those relating to the road and the vehicle (road layout, surface quality, vehicle power, maximum speed);

3. traffic- and environment-related (traffic density and composition, prevailing speed, weather conditions). (World Health Organization, 2004)

\section{How Speed Affects Traffic Collisions and Injuries}

The higher the speed of the vehicle, the faster the driver will stop and avoid collisions. Cars that travel at speeds of $50 \mathrm{~km} / \mathrm{h}$ usually require 13 meters to stop, while cars that travel at speeds of $40 \mathrm{~km} / \mathrm{h}$ will stop in less than 8.5 meters. 
An increase in the average speed of $1 \mathrm{~km} / \mathrm{h}$ usually results in a $3 \%$ higher risk of accidents involving injuries, with a 4-5\% increase in accidents resulting in death. - Speed also contributes to the severity of accidents. Impact when a collision occurs. For car passengers in an accident with a collision speed of $80 \mathrm{~km} / \mathrm{h}$, the probability of death is 20 times that which should be at the impact speed of $30 \mathrm{~km} /$ hour. (World Health Organization, 2004)

\section{Psychological Social Factors Underlying Behavior}

According to the Theory of Planned Behavior (TPB), when individuals have full control of their behaviour, individual behaviour can be predicted by their intention to display that behaviour. The emergence of this intention is based on three components, namely attitude (attitude), subjective norms (subjective norms), and perceptions of self-control of behaviour (Perceived behaviour control (Fishbein \& Ajzen, 1975). influenced by individual beliefs about a behaviour Subjective norm describes individual perceptions of the extent to which the social environment will support individuals to display certain behaviours. Furthermore, perceived behaviour controls describe individual perceptions of their ability to control internal and external factors that play a role in behaviour (Ajzen, 1985).

If the TPB theory is applied to speeding behaviour, it can be said that the driver's intention to display speeding behaviour is based on his attitude towards speeding behavior (for example, enjoying speeding), individual perceptions of subjective norms in his environment (for example, all friends often speed up, except timid people), and individual perceptions of how much they can control speeding behaviour (for example, no police officer supervises and gives tickets). When these three factors consistently provide information to individuals, eventually the intention will be to speed up and subsequently result in the behaviour of individuals doing or not doing speeding behaviour on the road (for example, individuals do not speed up because there are police who conduct raids, or individuals remain speeding up when the situation is quiet) (Shinar, 2007).

\section{METHODOLOGY}

\section{Survey of Vehicle Speed on the Highway Stages of Research}

The study location was chosen on the national road section in Jakarta, namely Jalan Daan Mogot. This road is a connecting road between Tangerang and Jakarta; access to this road is quite crowded because it is the main access to Jakarta to Tangerang and vice versa.

Traffic data retrieval is carried out on Thursday, June 20, 2019. Survey traffic counting using video recorders is carried out with a total duration of 12 hours namely $06.00-12.00$ (Morning Shift) and 15.00 - 21.00 (Evening Shift) in two directions namely Jakarta direction and Tangerang direction, taking this time is intended to get peak hour volume (VJP). Calculations are done manually using the hand counter separately through a video recorded on the survey day.

Calculated vehicles are classified into three types of vehicles;

1. Motorcycle;

2. Light Vehicle (LV);

3. Heavy Vehicle (HV). 


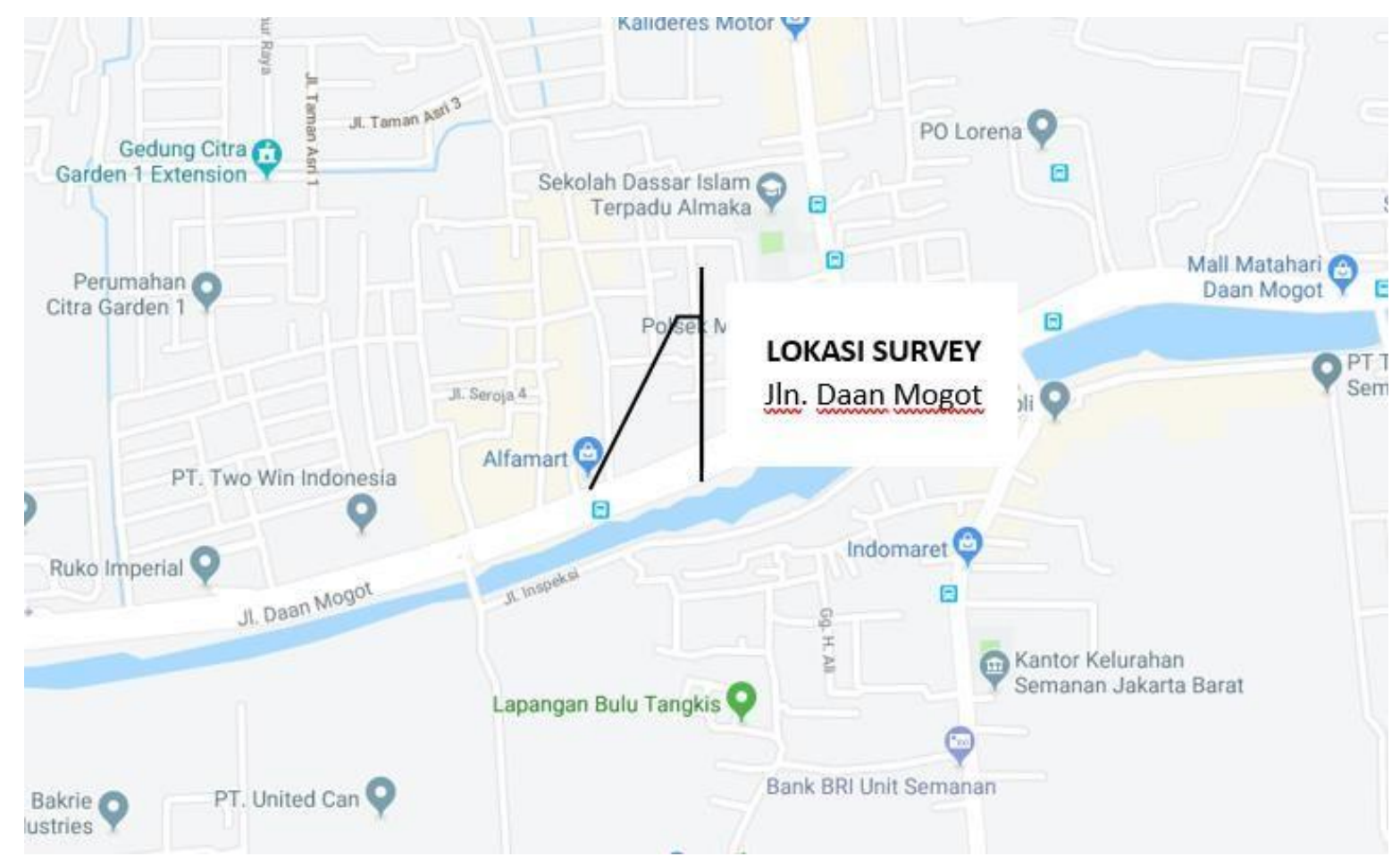

Figure 1. Location Survey

Spot Speed is also done to get the average speed value in the section. Speed data retrieval uses speed gun with each of the 30-speed data for the same three types of vehicles as traffic counting. Speed data retrieval is also carried out on two shifts, namely morning and evening.

\section{Research data}

Table 1. Vehicle speed data toward Jakarta

\begin{tabular}{|c|c|c|c|c|c|c|c|}
\hline \multirow{2}{*}{ Time } & \multicolumn{3}{|c|}{ Vehicle Speed $(\mathbf{k m} / \mathbf{h})$} & \multirow{2}{*}{ Time } & \multicolumn{3}{|c|}{ Vehicle Speed $(\mathrm{km} / \mathrm{h})$} \\
\hline & MC & $\mathbf{L V}$ & HV & & MC & $\mathbf{L V}$ & HV \\
\hline $6: 00-6: 15$ & 41 & 47 & 52 & $15: 00-15: 15$ & 39 & 32 & 32 \\
\hline $6: 15-6: 30$ & 47 & 51 & 51 & $15: 15-15: 30$ & 44 & 37 & 40 \\
\hline $6: 30-6: 45$ & 62 & 52 & 48 & $15: 30-15: 45$ & 37 & 39 & 32 \\
\hline $6: 45-7: 00$ & 44 & 45 & 52 & $15: 45-16: 00$ & 33 & 40 & 24 \\
\hline $7: 00-7: 15$ & 52 & 42 & 32 & $16: 00-16: 15$ & 40 & 36 & 44 \\
\hline $7: 15-7: 30$ & 61 & 53 & 33 & $16: 15-16: 30$ & 33 & 52 & 35 \\
\hline $7: 30-7: 45$ & 44 & 51 & 42 & $16: 30-16: 45$ & 43 & 31 & 36 \\
\hline $7: 45-8: 00$ & 48 & 25 & 39 & $16: 45-17: 00$ & 47 & 41 & 39 \\
\hline $8: 00-8: 15$ & 56 & 36 & 66 & $17: 00-17: 15$ & 40 & 37 & 37 \\
\hline $8: 15-8: 30$ & 48 & 58 & 40 & $17: 15-17: 30$ & 38 & 27 & 38 \\
\hline $8: 30-8: 45$ & 60 & 37 & 28 & $17: 30-17: 45$ & 47 & 45 & 34 \\
\hline $8: 45-9: 00$ & 56 & 51 & 46 & $17: 45-18: 00$ & 44 & 39 & 31 \\
\hline
\end{tabular}


Traffic Accident Research Centre

\begin{tabular}{|c|c|c|c|c|c|c|c|}
\hline \multirow{2}{*}{ Time } & \multicolumn{3}{|c|}{ Vehicle Speed $(\mathrm{km} / \mathrm{h})$} & \multirow{2}{*}{ Time } & \multicolumn{3}{|c|}{ Vehicle Speed $(\mathrm{km} / \mathrm{h})$} \\
\hline & MC & $\mathbf{L V}$ & HV & & MC & $\mathbf{L V}$ & HV \\
\hline $9: 00-9: 15$ & 63 & 42 & 21 & $18: 00-18: 15$ & 47 & 35 & 37 \\
\hline $9: 15-9: 30$ & 55 & 53 & 33 & $18: 15-18: 30$ & 41 & 42 & 56 \\
\hline $9: 30-9: 45$ & 56 & 40 & 50 & $18: 30-18: 45$ & 42 & 30 & 46 \\
\hline $9: 45-10: 00$ & 63 & 36 & 30 & $18: 45-19: 00$ & 46 & 40 & 34 \\
\hline $10: 00-10: 15$ & 55 & 51 & 50 & $19: 00-19: 15$ & 43 & 36 & 45 \\
\hline $10: 15-10: 30$ & 49 & 58 & 32 & $19: 15-19: 30$ & 39 & 48 & 28 \\
\hline $10: 30-10: 45$ & 63 & 48 & 40 & $19: 30-19: 45$ & 42 & 47 & 40 \\
\hline $10: 45-11: 00$ & 58 & 49 & 52 & $19: 45-20: 00$ & 48 & 42 & 54 \\
\hline $11: 00-11: 15$ & 46 & 52 & 47 & $20: 00-20: 15$ & 46 & 45 & 54 \\
\hline $11: 15-11: 30$ & 46 & 39 & 41 & $20: 15-20: 30$ & 35 & 40 & 34 \\
\hline $11: 30-11: 45$ & 58 & 40 & 39 & $20: 30-20: 45$ & 51 & 49 & 52 \\
\hline $11: 45-12: 00$ & 40 & 50 & 44 & $20: 45-21: 00$ & 42 & 47 & 42 \\
\hline $12: 00-12: 15$ & 60 & 53 & 56 & $21: 00-21: 15$ & 38 & 31 & 36 \\
\hline $12: 15-12: 30$ & 57 & 34 & 33 & $21: 15-21: 30$ & 34 & 37 & 24 \\
\hline $12: 30-12: 45$ & 52 & 53 & 42 & $21: 30-21: 45$ & 35 & 31 & 33 \\
\hline $12: 45-12: 00$ & 39 & 34 & 34 & $21: 45-22: 00$ & 24 & 36 & 29 \\
\hline $13: 00-13: 15$ & 57 & 38 & 42 & $22: 00-22: 15$ & 35 & 40 & 40 \\
\hline $13: 15-13: 30$ & 32 & 36 & 45 & $22: 15-22: 30$ & 24 & 34 & 46 \\
\hline
\end{tabular}

Table 2. Vehicle speed data toward Tangerang

\begin{tabular}{|c|c|c|c|c|c|c|c|}
\hline \multirow{2}{*}{ Time } & \multicolumn{3}{|c|}{ Vehicle Speed $(\mathrm{km} / \mathrm{h})$} & \multirow{2}{*}{ Time } & \multicolumn{3}{|c|}{ Vehicle Speed $(\mathbf{k m} / \mathbf{h})$} \\
\hline & MC & LV & HV & & MC & $\mathbf{L V}$ & HV \\
\hline $6: 00-6: 15$ & 43 & 42 & 43 & $15: 00-15: 15$ & 44 & 33 & 42 \\
\hline $6: 15-6: 30$ & 35 & 37 & 26 & $15: 15-15: 30$ & 53 & 33 & 33 \\
\hline $6: 30-6: 45$ & 51 & 40 & 28 & $15: 30-15: 45$ & 37 & 33 & 53 \\
\hline $6: 45-7: 00$ & 37 & 26 & 23 & $15: 45-16: 00$ & 42 & 35 & 37 \\
\hline $7: 00-7: 15$ & 38 & 34 & 31 & $16: 00-16: 15$ & 40 & 41 & 44 \\
\hline $7: 15-7: 30$ & 38 & 43 & 29 & $16: 15-16: 30$ & 37 & 71 & 50 \\
\hline $7: 30-7: 45$ & 30 & 43 & 33 & $16: 30-16: 45$ & 67 & 4 & 54 \\
\hline $7: 45-8: 00$ & 32 & 50 & 35 & $16: 45-17: 00$ & 65 & 59 & 47 \\
\hline $8: 00-8: 15$ & 36 & 41 & 49 & $17: 00-17: 15$ & 51 & 50 & 30 \\
\hline $8: 15-8: 30$ & 47 & 38 & 35 & $17: 15-17: 30$ & 49 & 60 & 37 \\
\hline $8: 30-8: 45$ & 33 & 35 & 42 & $17: 30-17: 45$ & 42 & 53 & 36 \\
\hline $8: 45-9: 00$ & 50 & 43 & 29 & $17: 45-18: 00$ & 36 & 33 & 35 \\
\hline
\end{tabular}




\begin{tabular}{|c|c|c|c|c|c|c|c|}
\hline \multirow{2}{*}{ Time } & \multicolumn{3}{|c|}{ Vehicle Speed $(\mathbf{k m} / \mathbf{h})$} & \multirow{2}{*}{ Time } & \multicolumn{3}{|c|}{ Vehicle Speed $(\mathrm{km} / \mathrm{h})$} \\
\hline & MC & $\mathbf{L V}$ & HV & & MC & $\mathbf{L V}$ & HV \\
\hline $9: 00$ - 9:15 & 35 & 45 & 37 & $18: 00-18: 15$ & 41 & 43 & 43 \\
\hline $9: 15-9: 30$ & 22 & 41 & 47 & $18: 15-18: 30$ & 36 & 39 & 39 \\
\hline $9: 30-9: 45$ & 38 & 24 & 35 & $18: 30-18: 45$ & 49 & 43 & 35 \\
\hline $9: 45-10: 00$ & 17 & 18 & 40 & $18: 45-19: 00$ & 56 & 50 & 48 \\
\hline 10:00 - 10:15 & 22 & 51 & 28 & 19:00 - 19:15 & 45 & 59 & 51 \\
\hline $10: 15-10: 30$ & 12 & 45 & 34 & $19: 15-19: 30$ & 49 & 43 & 63 \\
\hline $10: 30-10: 45$ & 16 & 45 & 31 & $19: 30-19: 45$ & 40 & 68 & 39 \\
\hline 10:45 - 11:00 & 18 & 43 & 19 & 19:45 - 20:00 & 47 & 55 & 39 \\
\hline 11:00 - 11:15 & 18 & 42 & 33 & $20: 00-20: 15$ & 37 & 49 & 42 \\
\hline $11: 15-11: 30$ & 18 & 42 & 30 & $20: 15-20: 30$ & 70 & 46 & 52 \\
\hline $11: 30-11: 45$ & 13 & 43 & 31 & $20: 30-20: 45$ & 52 & 51 & 48 \\
\hline 11:45 - 12:00 & 10 & 37 & 32 & $20: 45-21: 00$ & 24 & 39 & 36 \\
\hline $12: 00-12: 15$ & 20 & 46 & 32 & $21: 00-21: 15$ & 45 & 47 & 42 \\
\hline $12: 15-12: 30$ & 23 & 48 & 22 & $21: 15-21: 30$ & 64 & 46 & 41 \\
\hline $12: 30-12: 45$ & 32 & 42 & 33 & $21: 30-21: 45$ & 65 & 47 & 39 \\
\hline $12: 45-12: 00$ & 29 & 48 & 48 & $21: 45-22: 00$ & 58 & 39 & 43 \\
\hline $12: 00-12: 15$ & 25 & 35 & 35 & $22: 00-22: 15$ & 55 & 55 & 43 \\
\hline $12: 15-12: 30$ & 32 & 46 & 46 & $22: 15-22: 30$ & 42 & 60 & 60 \\
\hline
\end{tabular}

\section{RESULTS AND DISCUSSION}

\section{Plan Speed 50 km/hour}

Based on Figure 1 on the Daan Mogot road towards Jakarta in the morning from each vehicle, there is nothing that reaches speeds of $50 \mathrm{~km} /$ hour, this can be due to the direction of Jakarta morning that the road conditions are quite dense, so it does not allow the vehicle to run at speeds above $50 \mathrm{~km}$ /hour. So that it can be said that vehicles passing in the direction of Jakarta at 6:00 - 12:00 are still at a safe speed. 


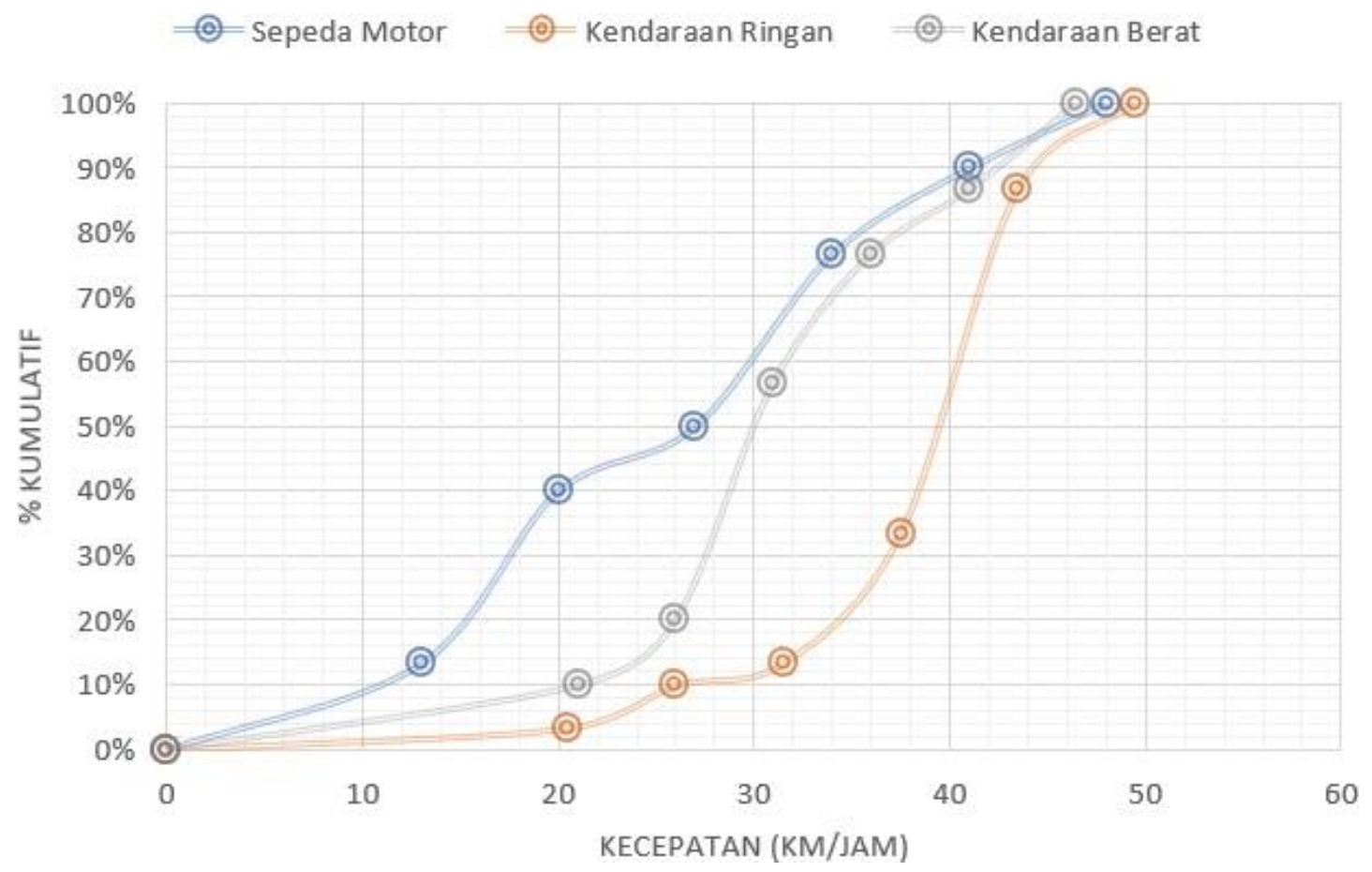

Figure 2. Cumulative percentage of plan speed $50 \mathrm{~km} / \mathrm{h}$ Jakarta (morning)

Based on Figure 2 on the Daan Mogot road towards Jakarta in the afternoon at the planned speed of $50 \mathrm{~km} / \mathrm{h}$ for motorcycles, it has a cumulative percentage of $74 \%$ for passenger vehicles at $79 \%$ and for heavy vehicles at $86 \%$. So, the percentage of vehicles that run above the plan speed $(50 \mathrm{~km} / \mathrm{h})$ is on motorbikes at $26 \%$, on passenger vehicles at $21 \%$, and on heavy vehicles at $14 \%$.

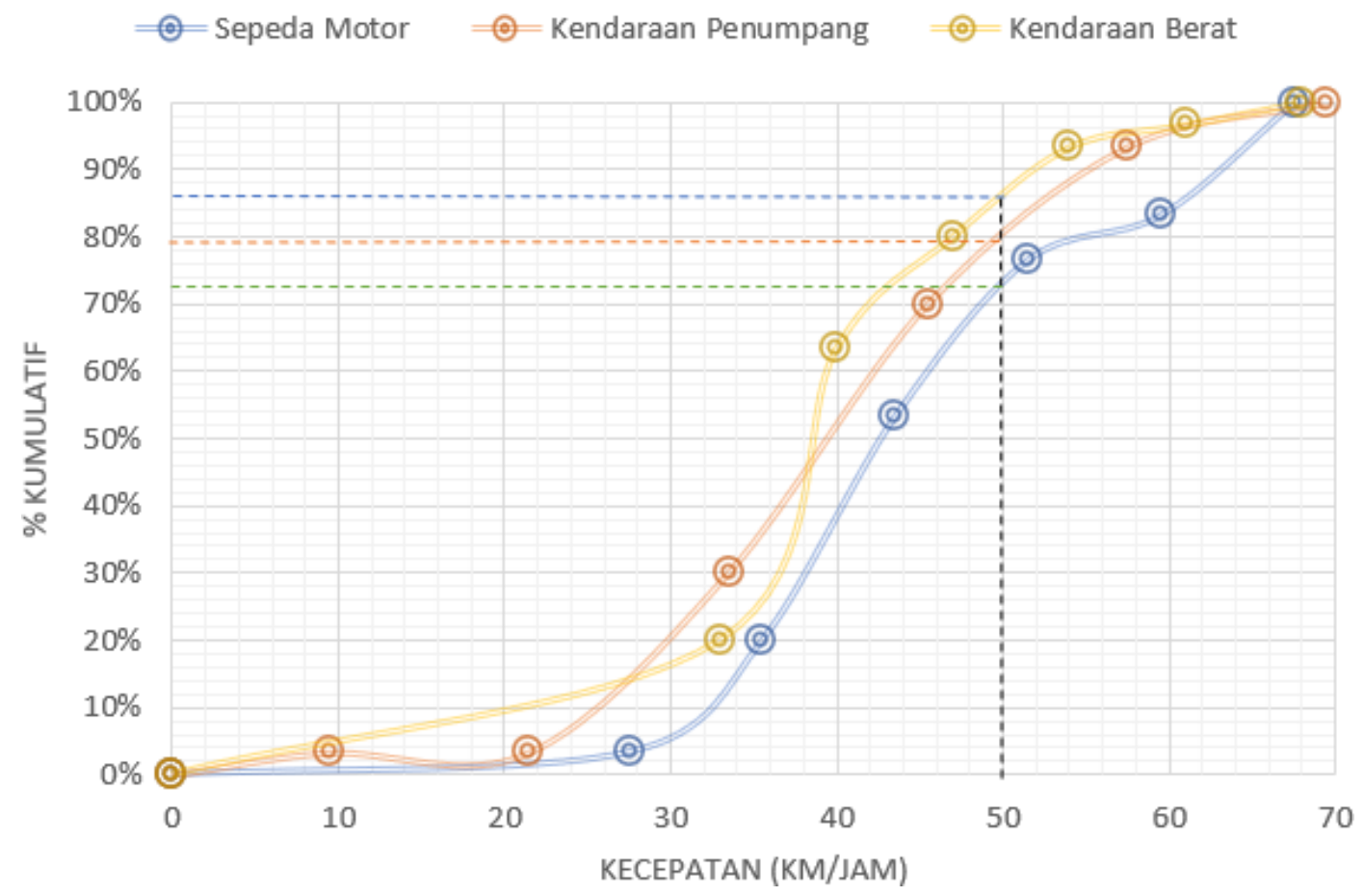

Figure 3. Cumulative percentage of plan speed $50 \mathrm{~km} / \mathrm{h}$ Jakarta (afternoon) 
Based on Figure 3 on Daan Mogot road towards Tangerang in the morning at the planned speed of $50 \mathrm{~km} / \mathrm{h}$ for motorcycles, it has a cumulative percentage of $46 \%$ for passenger vehicles at $85 \%$ and for heavy vehicles at $90 \%$. The percentage of vehicles that go above the planned speed $(50 \mathrm{~km} / \mathrm{h})$ on the Daan Mogot road in Jakarta from 15:00 to 21:00 that is on motorbikes by $54 \%$, on passenger vehicles by $15 \%$ and on heavy vehicles by $10 \%$.

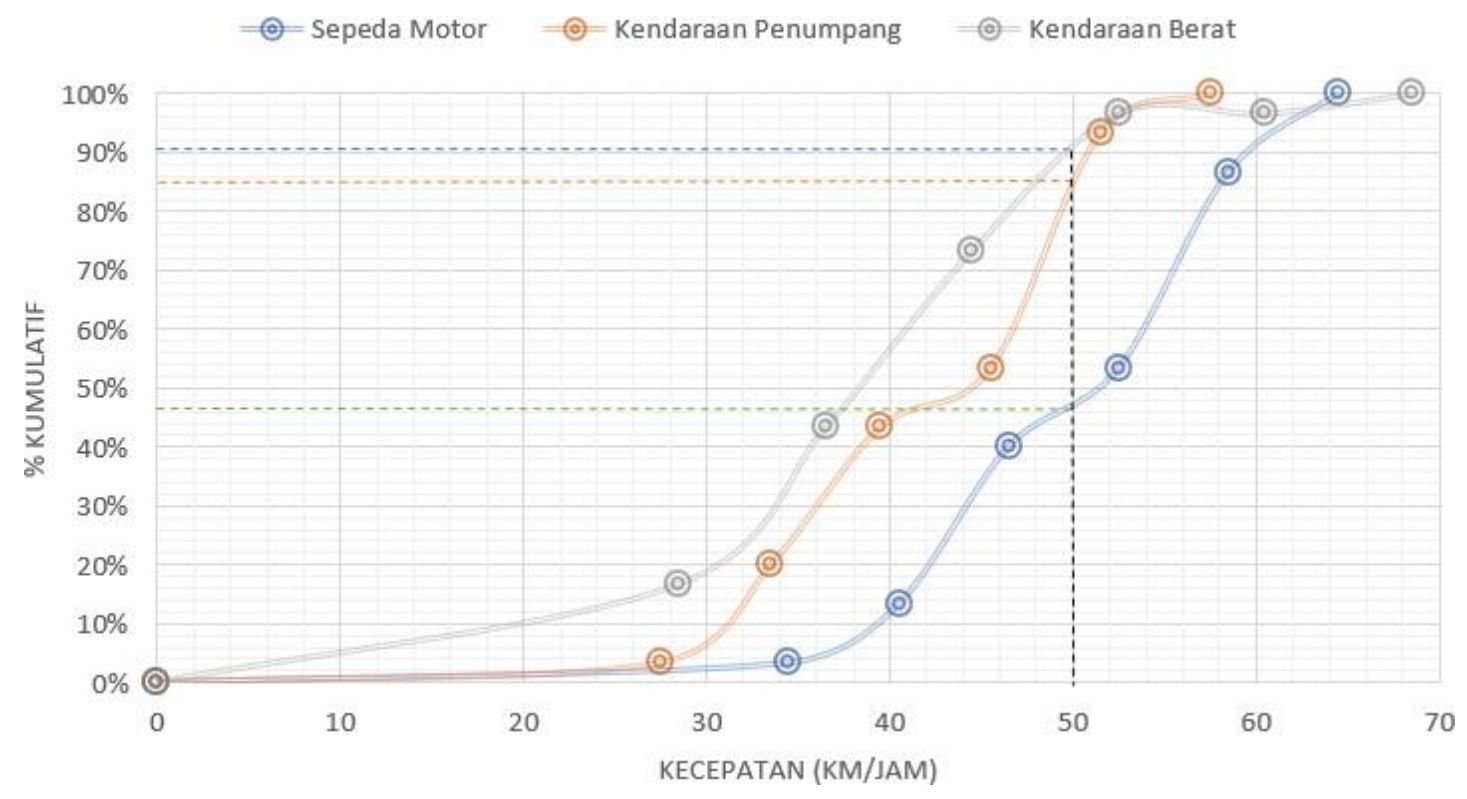

Figure 4. Cumulative percentage of plan speed $50 \mathrm{~km} /$ hour Tangerang (morning)

Based on Figure 4 on Daan Mogot road towards Tangerang in the afternoon at the planned speed of $50 \mathrm{~km} / \mathrm{h}$ for motorbikes, it has a cumulative percentage of $99 \%$ for passenger vehicles $93 \%$ and for heavy vehicles $91 \%$. The percentage of vehicles that runs above the plan speed is on motorbikes by $1 \%$, on passenger vehicles $7 \%$, and on heavy vehicles at $9 \%$.

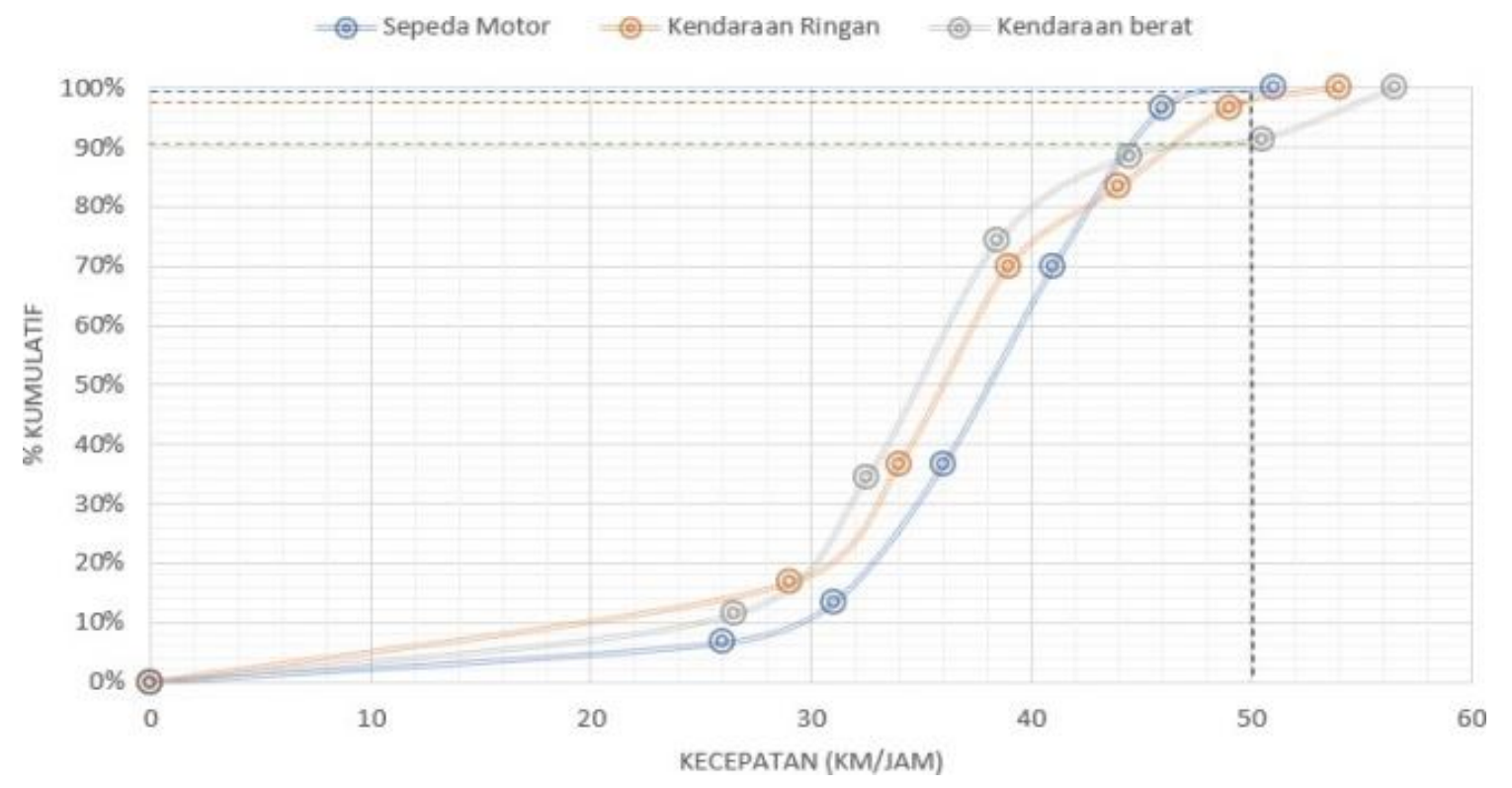

Figure 5. Cumulative percentage of plan speed $50 \mathrm{~km} / \mathrm{h}$ Tangerang (afternoon) 


\section{Speed of 85 Percentiles}

From picture 5 speed that speed is often used by the driver ( 85 percentile speed) on the Daan Mogot road in Jakarta (morning) that is for motorbikes at $38 \mathrm{~km} / \mathrm{h}$, for light vehicles at $40 \mathrm{~km} / \mathrm{h}$ and vehicles are weighing $42,65 \mathrm{~km} / \mathrm{h}$.

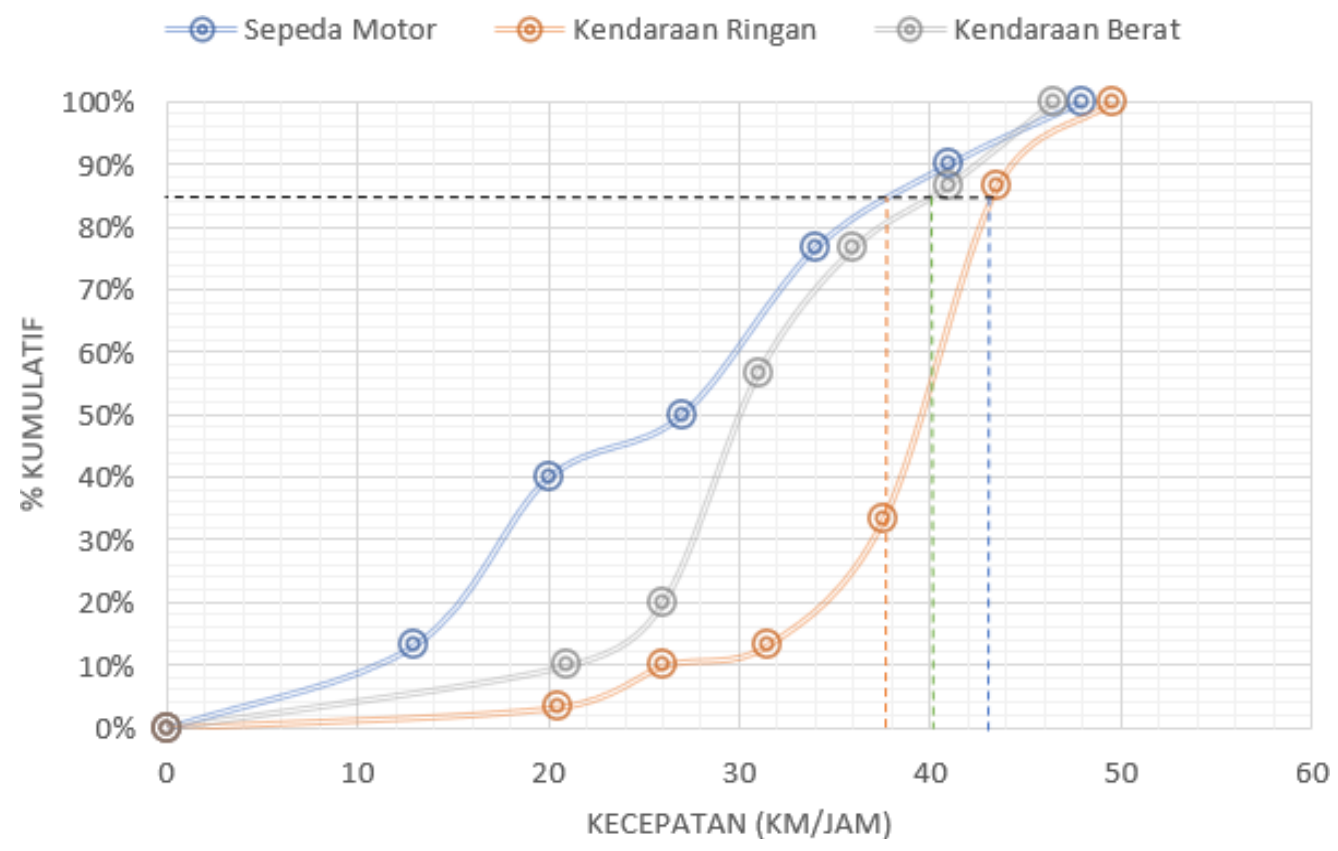

Figure 6. Speed 85 percentile toward Jakarta (morning)

From figure 6 speed, that speed is often used by the driver ( 85 percentile speed) on the road Daan Mogot in Jakarta (afternoon) that is for motorcycles $60.2 \mathrm{~km} / \mathrm{hour}$ for light vehicles $52.65 \mathrm{~km} / \mathrm{h}$ for and vehicles weight of $49 \mathrm{~km} / \mathrm{h}$.

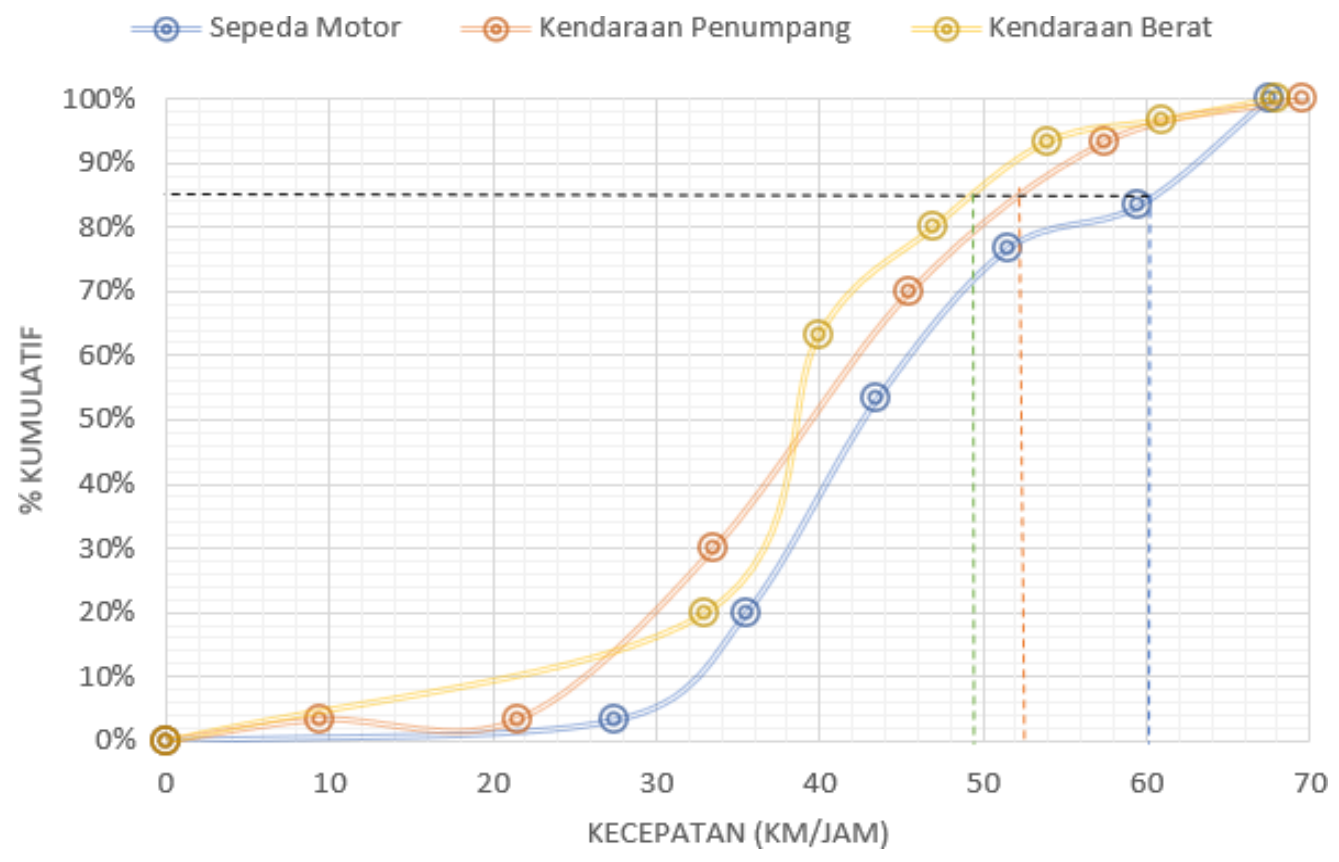

Figure 7. Speed 85 percentile toward Jakarta (afternoon) 
From the 7-speed image that the speed that is often used by the driver ( 85 percentile speed) on the Daan Mogot road in the direction of Tangerang (afternoon) for motorbikes 46.3 $\mathrm{km} / \mathrm{h}$ for, for light vehicles at $43.7 \mathrm{~km} / \mathrm{h}$ and heavy vehicles at $42 \mathrm{~km} / \mathrm{h}$.

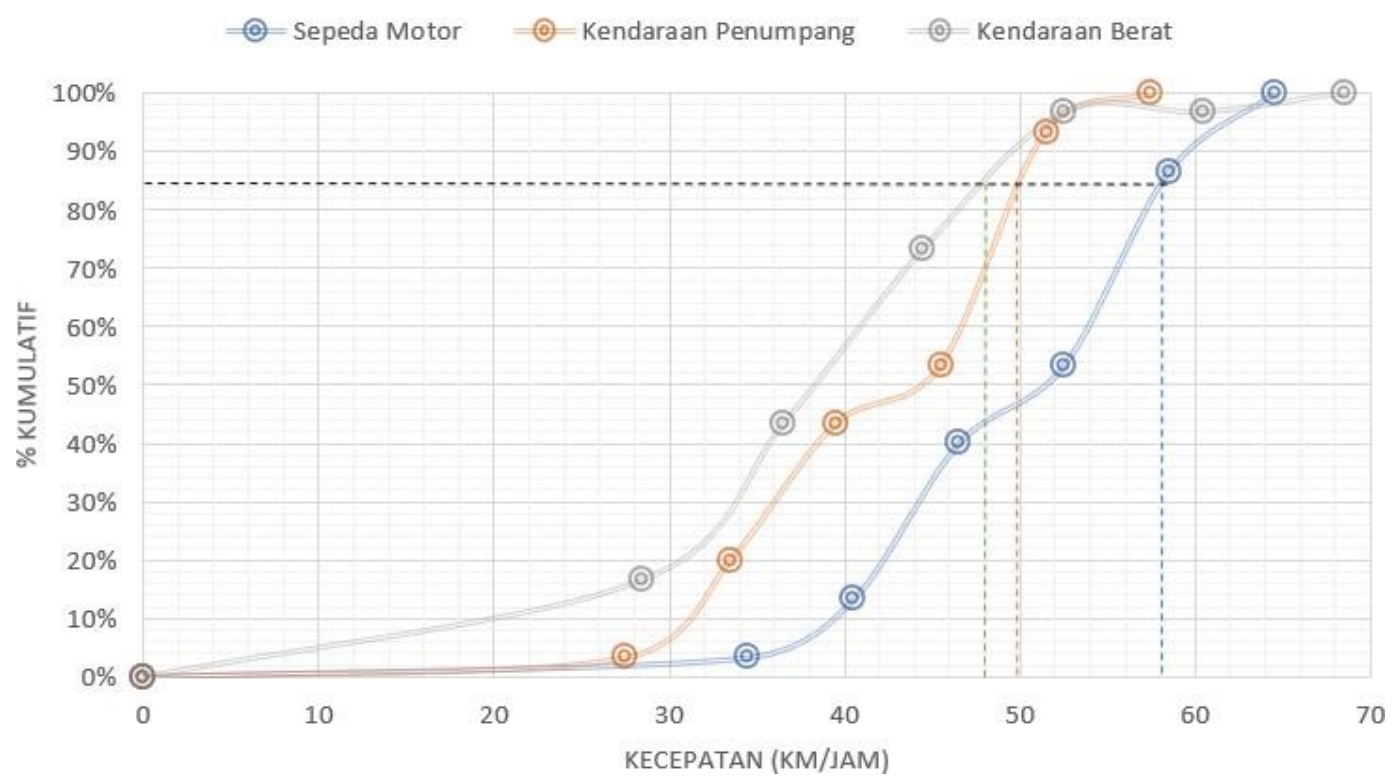

Figure 8. Speed 85 percentile toward Tangerang (morning)

From figure 8 speed that speed is often used by the driver ( 85 percentile speed) on the Daan Mogot road in the direction of Tangerang (afternoon) for motorbikes $58 \mathrm{~km} / \mathrm{h}$ for, for light vehicles at $50.35 \mathrm{~km} / \mathrm{h}$ and vehicles weighing $48 \mathrm{~km} / \mathrm{h}$.

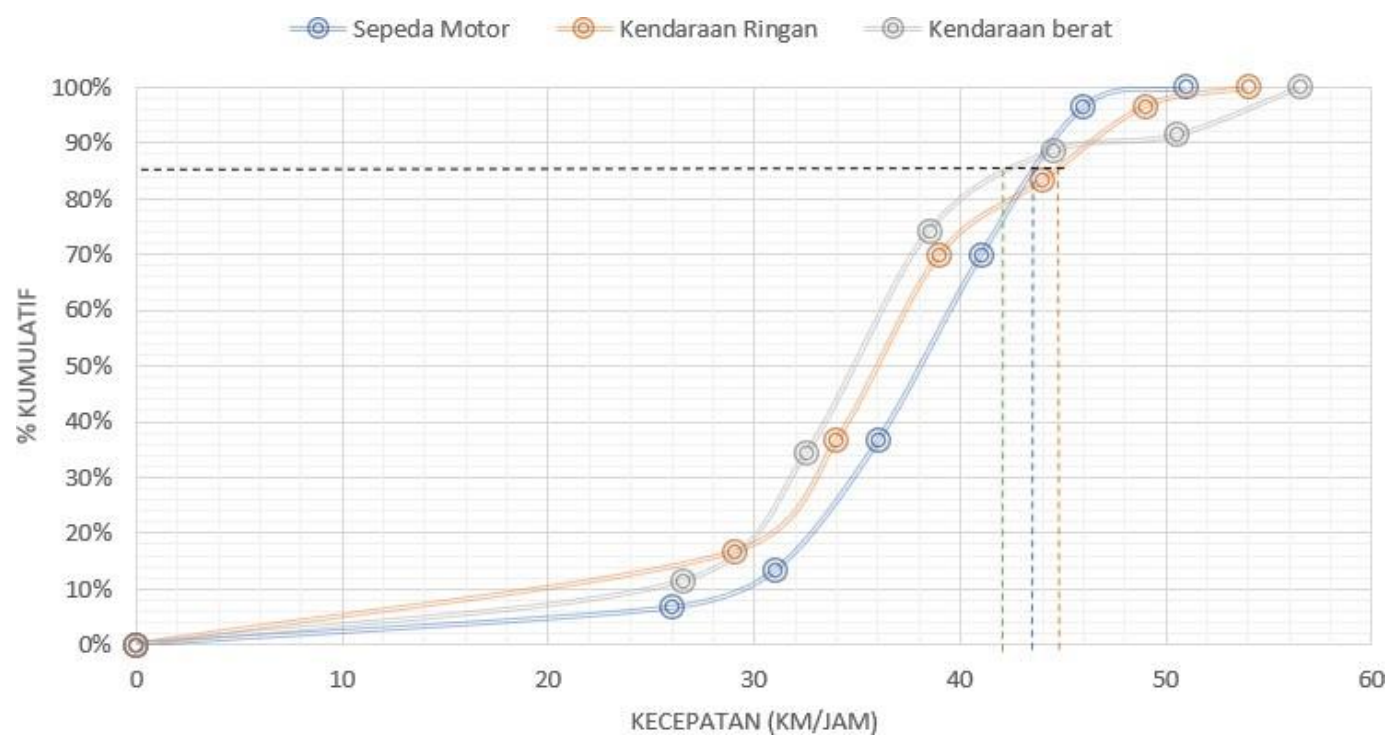

Figure 9 Speed 85 percentile toward Tangerang (afternoon)

\section{Survey of Psychological Social Factors of Speeding Behavior on Drivers Demographic Description and Driving Behavior of Participants}

Demographic data, as shown in Table 1, shows that the majority of participants who filled out the questionnaire were car drivers $(69.6 \%)$. The percentage of male and female drivers 
is quite balanced, with an age range between 17 to 68 years $(\mathrm{M}=36.27, \mathrm{SD}=13.26)$. The majority of education participants are S1 $(45.1 \%)$ and then high school (22.5\%). Fifty per cent of participants have more than 2 SIMs, which is a combination of SIM B1, SIM A, and SIM C. The majority of participants are experienced drivers, which is more than ten years (62.7\%). Participants were active car and motorcycle drivers, who, on average, drove for 3 hours per day $(\mathrm{M}=3.87, \mathrm{SD}=7.83)$. Most participants had never received a ticket in the past year (79.4\%) and had never had an accident in the past year (82.4\%).

Table 3. Demographic overview and participant driving behaviour $(\mathrm{N}=102)$

\begin{tabular}{|c|c|c|c|c|c|c|}
\hline No. & Demographic I & tem & $\mathbf{n}$ & $\%$ & $\mathbf{M}$ & SD \\
\hline \multirow[t]{2}{*}{1.} & \multirow[t]{2}{*}{ Gender } & Man & 59 & 57.8 & & \\
\hline & & Women & 43 & 42.2 & & \\
\hline \multirow[t]{5}{*}{2.} & \multirow[t]{5}{*}{ Age } & & & & 36.27 & 13.26 \\
\hline & & $17-25$ years & 27 & 26.5 & & \\
\hline & & $26-40$ years old & 37 & 36.3 & & \\
\hline & & 41-60 years & 35 & 34.3 & & \\
\hline & & $>60$ years old & 3 & 2.9 & & \\
\hline \multirow[t]{6}{*}{3.} & \multirow[t]{6}{*}{ Education } & Junior high school & 3 & 2.9 & & \\
\hline & & High school & 23 & 22.5 & & \\
\hline & & D3 & 4 & 3.9 & & \\
\hline & & S1 & 46 & 45.1 & & \\
\hline & & S2 & 21 & 20.6 & & \\
\hline & & S3 & 5 & 4.9 & & \\
\hline \multirow[t]{2}{*}{4} & \multirow[t]{2}{*}{ Transportation type } & Motorcycle & 31 & 30.4 & & \\
\hline & & Car & 71 & 69.6 & & \\
\hline \multirow[t]{3}{*}{5.} & \multirow[t]{3}{*}{ SIM ownership } & SIM A & 44 & 37.3 & & \\
\hline & & SIM C & 4 & 18.6 & & \\
\hline & & More than 2 SIM & 54 & 52.94 & & \\
\hline \multirow[t]{4}{*}{6.} & \multirow[t]{4}{*}{ Driving experience (years) } & Less than 3 year & 6 & 5.9 & & \\
\hline & & Between 3-5 year & 14 & 13.7 & & \\
\hline & & Between 6-10 year & 18 & 17.6 & & \\
\hline & & More than 10year & 64 & 62.7 & & \\
\hline \multirow[t]{3}{*}{7.} & \multirow{3}{*}{$\begin{array}{l}\text { The frequency of getting a ticket } \\
\text { in the past year }\end{array}$} & Never & 81 & 79.4 & & \\
\hline & & $1-2$ times & 18 & 17.6 & & \\
\hline & & $>2$ times & 3 & 2.9 & & \\
\hline \multirow[t]{3}{*}{8.} & \multirow{3}{*}{$\begin{array}{l}\text { The frequency of having an } \\
\text { accident in the past year }\end{array}$} & Never & 84 & 82.4 & & \\
\hline & & $1-2$ times & 17 & 16.6 & & \\
\hline & & $>2$ times & 1 & 1.0 & & \\
\hline 9. & Duration of driving (hours/day) & & & & 3.87 & 7.83 \\
\hline
\end{tabular}




\section{Participant Perception Regarding Speed Limits When Driving}

There are three main reasons, according to participants, regarding the implementation of vehicle speed limits in Indonesia, namely to reduce accidents, control vehicles when facing sudden situations, and increase alertness when visibility does not meet the requirements (Table 4). The three main reasons are related to the driver's efforts to increase his ability and concentration while driving and avoiding accidents. This shows that according to participants, the speed of the vehicle is closely related to the possibility of an accident on the highway.

Table 4. Reasons for the Importance of Implementing Speed Limits in Indonesia

\begin{tabular}{llc}
\hline \multicolumn{1}{c}{ Description } & $\mathbf{n}$ & \% \\
\hline Reducing accidents & 57 & 55.9 \\
\hline Can control the vehicle if facing a sudden situation & 52 & 51.0 \\
\hline Increase alertness when distance view does not meet the requirements & 39 & 38.2 \\
\hline
\end{tabular}

According to participants' perceptions, there are differences in the maximum speed limits according to the type of road (Table 5 ). The lowest vehicle speed limit is when on a 2 lane road with 2 opposite directions, which is $48 \mathrm{~km} / \mathrm{hr}$. On the other hand, the highest vehicle speed limit is when on the highway, which is $89 \mathrm{~km} /$ hour.

Table 5. Maximum speed limit

\begin{tabular}{lcc}
\hline \multicolumn{1}{c}{ Description } & $\boldsymbol{M}$ & $\boldsymbol{S D}$ \\
\hline Two lines in two opposite directions & 48.24 & 16.66 \\
\hline Two lines in the same direction & 63.04 & 22.11 \\
\hline Expressway (toll road) & 89.17 & 23.75 \\
\hline
\end{tabular}

One driving behavior related to vehicle speed is speeding behavior (Table 6 ). When performing speeding behavior, the driver displays the speed of the vehicle that is different according to the type of road. On a two-lane road with 2 opposite directions, the speed of the vehicle when speeding is $59 \mathrm{~km} / \mathrm{hr}$. Different things are found on a two-lane road but in the same direction, where the speed of the participant when speeding is around $73 \mathrm{~km} / \mathrm{hr}$. The highest driving speed when speeding is on the toll road, which is $107 \mathrm{~km} / \mathrm{hour}$.

Table 6. Speed when speeding

\begin{tabular}{lcc}
\hline \multicolumn{1}{c}{ Description } & $\boldsymbol{M}$ & $\boldsymbol{S D}$ \\
\hline Two lines in two opposite directions & 59.76 & 21.92 \\
\hline Two lines in the same direction & 73.05 & 23.52 \\
\hline Expressway (toll road) & 107.84 & 32.02 \\
\hline
\end{tabular}

\section{Driver's Psychological Social Aspects Regarding Speeding Behavior}

In terms of social psychological aspects, participants generally had a negative attitude towards speeding behavior $(\mathrm{M}=2.04, \mathrm{SD}=.67)$. A positive attitude towards behavior only appears when speeding is perceived to satisfy the driver's desire to arrive at his destination 
faster $(\mathrm{M}=2.62, \mathrm{SD}=.99)$. This negative attitude towards speeding behaviour is related to participants' belief in speeding behaviour. In general, participants have confidence that speeding behaviour is a behaviour that is too dangerous and increases the risk of accidents $(\mathrm{M}=2.23, \mathrm{SD}=.84)$. Speeding behaviour is considered not too dangerous only when done in quiet road conditions ( $\mathrm{M}=2.53, \mathrm{SD}=.94)$.

Participants also perceived a lack of support from the environment or people who are meaningful in their lives, such as family, friends, fellow drivers, and police to display speeding behaviour $(\mathrm{M}=2.00, \mathrm{SD}=.59)$. The perceived party gives the strongest influence to prevent them from carrying out speeding behavior is friends and police (Table 7 ).

The results of the study also showed that participants perceived themselves as having less control to determine speeding behaviour $(\mathrm{M}=2.12, \mathrm{SD}=.56)$. They only speed up if it can make them faster and on time to get to their destination (Table 9).

Table 7. Psychological social aspects regarding speeding behaviour

\begin{tabular}{lccc}
\hline & Description & $\boldsymbol{M}$ & $\boldsymbol{S D}$ \\
\hline Attitude & 2.04 & .67 \\
\hline Belief & 2.23 & .84 \\
\hline Subjective norm & 2.00 & .59 \\
\hline PBC & 2.12 & .56 \\
\hline
\end{tabular}

* Scale 1-4

Table 8. Attitude related to speeding behaviour

\begin{tabular}{lcc}
\hline \multicolumn{1}{c}{ Description } & $\boldsymbol{M}$ & $\boldsymbol{S D}$ \\
\hline Speeding can satisfy the driver's desire to reach their destination faster & 2.62 & .99 \\
\hline Speeding makes the driver feel freer in channelling emotions & 2.07 & .88 \\
\hline Speeding makes the driver more confident in his ability to drive a vehicle & 1.99 & .86 \\
\hline Speeding makes the driver proud because he can overtake other vehicles & 1.91 & .82 \\
\hline Not speeding on the highway signifies a cowardly driver & 1.47 & .57
\end{tabular}

Speeding makes the driver more excited in driving

* Scale 1-4

Table 9. Belief related to speeding behaviour

\begin{tabular}{lcc}
\hline \multicolumn{1}{c}{ Description } & $\boldsymbol{M}$ & $\boldsymbol{S D}$ \\
\hline Increase the likelihood of the driver having an accident & 2.14 & .89 \\
\hline Endanger the driver & 2.15 & .93 \\
\hline Injuring other people on the highway & 2.21 & .96 \\
\hline Injuring passengers in the driver's vehicle & 2.26 & .96 \\
\hline Causing accidents in slippery road conditions & 2.05 & .95 \\
\hline Causing accidents in quiet road conditions & 2.53 & .94 \\
\hline Cause accidents in two-way road conditions & 2.26 & .92 \\
\hline
\end{tabular}

* Scale 1-4 
Table 10. Subjective norms related to speeding behaviour

\begin{tabular}{lcc}
\multicolumn{1}{c}{ Description } & $\boldsymbol{M}$ & $\boldsymbol{S D}$ \\
\hline Friends encourage to speed up & 1.8 & .70 \\
\hline Families let drivers drive in forced conditions & 1.90 & .81 \\
\hline The police will let the driver speed when the road is not crowded & 1.87 & .81 \\
\hline Fellow drivers want the driver to drive the vehicle at a higher speed & 1.95 & .76 \\
\hline $\begin{array}{l}\text { The police care more about the completeness of vehicle documents than } \\
\text { the driver who drove }\end{array}$ & 2.48 & 1.04 \\
\hline
\end{tabular}

* Scale 1-4

Table 11. Perceived Behavior Control (PBC) related to Speeding Behavior

\begin{tabular}{lcc}
\hline \multicolumn{1}{c}{ Description } & $\boldsymbol{M}$ & $\boldsymbol{S D}$ \\
\hline Get to your destination faster & 3.02 & .83 \\
\hline Reach the destination on time & 2.89 & .77 \\
\hline Given the opportunity to test guts & 1.84 & .84 \\
\hline Reduce stress & 1.88 & .85 \\
\hline Fun driving & 2.25 & .89 \\
\hline Eliminate drowsiness & 2.13 & .89 \\
\hline Improve concentration on the road & 2.24 & .85 \\
\hline Demonstrate the ability to drive to other drivers & 1.75 & .74 \\
\hline Channel anger & 1.99 & .92 \\
\hline Get praise from people around & 1.62 & .65 \\
\hline Escaped from police capture & 1.75 & .87 \\
\hline
\end{tabular}

* Scale 1-4

\section{CONCLUSION AND SUGGESTION}

\section{Conclusion}

1. From the results of the analysis on Daan Mogot road in both the direction of Jakarta and the direction of Tangerang vehicles that use a plan speed of $50 \mathrm{~km} / \mathrm{h}$ are as much as more than $45 \%$.

2. Vehicles that use vehicles above the planned speed are generally motorbikes with 26$54 \%$.

3. From the calculation of the speed of 85 percentiles, the speed used by 85 per cent of the drivers on the Daan Mogot road ranges from speeds of $40 \mathrm{~km} / \mathrm{h}-58 \mathrm{~km} / \mathrm{hr}$.

4. Based note that on the road D and $M$ got both from Jakarta and Tangerang driver potentially increasing the speed of the vehicle at 16:00 and above

5. Drivers have a negative attitude towards speeding behaviour. This is related to the belief that speeding behaviour is classified as dangerous behaviour and can increase the likelihood of accidents. 
6. Drivers lack support from the environment to display speeding behaviour on the road, especially from fellow drivers and police. This makes the driver feel less control and has many obstacles to display speeding behaviour.

\section{Suggestion}

1. The driver should control speed control by paying attention to the plan/design speed on the road.

2. There needs to be socialization to the driver that speeding behaviour will bring more risks than profits. Speeding behaviour is still considered dangerous and risks causing accidents even though it is done in a quiet place. Also, socialization needs to emphasize that the benefits of being able to get faster through speeding are not proportional to the risk of accidents that can be displayed from speeding behaviour. Speeding behaviour can endanger not only the driver but also other drivers on the highway.

\section{UNKNOWLEDGEMENT}

Thanks to the Journal of Indonesia Road Safety - the Traffic Accident Research Center has funded and the Metro Jaya Regional Police that collaborated in this study.

\section{BIBLIOGRAPHY}

Abraham. (2001). Analysis of Highway Speed Limits. Thesis Faculty of Applied Science and Engineering University Toronto, Canada.

Presiden Republik Indonesia. (2013). Peraturan Pemerintah No 79 Tahun 2013 tentang Jaringan Lalu Lintas dan Angkutan Jalan.

Sendow, T. K. (2004). Analisa Jarak Pandangan di Lengkung Horisontal dan Lengkung Vertikal. Tesis Program Magister Teknik Sipil,Institut Teknologi Bandung.

Transport Research Center. (2006). Speed Management. France: OECD.

World Health Organization. (2004). Fact Road Safety. Road Safety is Not Accident. BjØrnskau, T., Nævestad, T. O., \& Akhtar, J. (2011). Traffic safety among motorcyclists in

Norway: A study of subgroups and risk factors. Accident Analysis and Prevention. DOI: 10.1016/j.aap.2011.09.051.

Chang, H. L., \& Yeh, T. H. (2007). Motorcyclist accident involvement by age, gender, and risky behaviors in Taipei, Taiwan. Transportation Research Part F, 10, 109-122.

Cheng, A. S. K. \& Lee, H. C. (2012). Risk-taking behavior and response inhibition of commuter motorcyclists with different levels of compulsivity. Transportation Research Part F, 15, 535-543.

Fishbein, M. and I. Ajzen (1975). Belief; attitude, intention and behavior. AddisonWesley, New York.

Shinar, D. (2007). Traffic safety and human behavior. Netherlands: Elsevier 